\title{
GENIUS LOCI - BRNO 2012
}

\section{Pohled do minula a zadání tématu}

Za tímto řečnickým pultem jsem stával dlouhá léta jako předseda brněnských mezinárodních hudebněvědných kolokvií a řídil je se svými spolupracovníky a žáky od roku 1968 až do mého emeritování roku 1990, kdy pak jejich řízení po mně převzal Jiří Fukač. Každoroční mezinárodní hudebněvědná kolokvia v Brně založil roku 1966 Rudolf Pečman. Před tím se konala jen nepravidelně z podnětu našeho společného učitele profesora Jana Racka, doktora historických věd. Památný byl zejména Mezinárodní hudebněvědecký kongres Leoš Janáček a soudobá hudba v roce 1958, kterého se zúčastnili vedle domácích muzikologů i hudební vědci z obou částí tehdy rozdělené Evropy, ojediněle i z Ameriky, Japonska a Jihoafrické republiky. Leoš Janáček se octl poprvé ve výhni svobodně vedených úvah mezinárodní muzikologické obce. Ke zvědomění smyslu a významu jeho hudebního génia přispělo i provedení téměř celého díla na festivalu. Pomáhali jsme profesoru Rackovi v organizačních věcech, přednesli jsme poprvé na mezinárodním fóru i referáty. Naučili jsme se kolokvijním manýrám a sami jsme pak kolokvia pořádali. Za nelehkých okolností se nám dařilo udržovat jejich svobodného ducha a mezinárodní prestiž.

$\mathrm{V}$ devadesátých letech jsem se zúčastňoval kolokvií již jenom jako referent, př́ležitostně navrhoval některá témata. Jedno z nich bylo Richard Wagner a hudebni kultura slovanských národů, o němž jsem přednášel roku 1995 na kongresu Richard Wagner International v západoněmeckém Baden-Badenu, proslulém svými hernami a kultem nové hudby. V upravené podobě jsem tento text přednesl na brněnském wagnerovském kolokviu. Vyšel v časopise Opus musicum. Byla to moje brněnská kolokvijní derniéra. K přednáškám a kolokviím jsem byl zván i v cizině.

Něco více než před měsícem jsem však byl překvapen výzvou, abych se ujal úvodního proslovu na kolokviu druhého ročníku Bienále Janáček Brno. Zprvu jsem vůbec váhal, zda mám pozvání přijmout, a to i pro krátkost času na jeho vypracování. Uvědomil jsem si však, že pozvání pro mne znamenalo i jistý druh pocty, a tak jsem výzvu přijal. Pro vystoupení na kolokviu jsem si v souladu 
s dramaturgií festivalu zvolil téma „génius loci Brno“, které bylo jako takové představenstvem kolokvia přijato. Poněkud zvláštní volbou jsem se chtěl vyvarovat pouhého převyprávění věcí významných a méně významných. Snad jsem se tím dostal za tyto hranice a byl jsem přiveden $\mathrm{k}$ některým novým myšlenkám, které jsem do proslovu zařadil, možná že někde i přes původně jen míněný muzikologický rámec. Takovéto sdělení však vyžaduje nejdříve vymezení pojmu, jehož je někdy používáno publicisty k pochvale skladatele nebo hudebního díla (používají k tomu výrazů o světovosti).

\section{K vymezení pojmu}

Pojem génia znali již staří Řekové a Římané. Idealista Platón v něm spatřoval „božské šilenství básníka“. V latinských pramenech byl „génius duch strážný, provázejicí člověka od jeho zplození a narozeni celýživot, sdílejicí s ním slasti a strasti, ano i po smrti jakožto božský dar s ním žijicíi." A dále se v pramenech praví: „Jako každý člověk mělo každé misto, krb, město i stát svého génia."V realitě života byl uctíván jako génius císař Augustus. Jeho doba byla zlatým věkem římské kultury, např́klad básníkủ Vergilia, Horatia, Ovidia. V pohledu současníka to však nebyli géniové. Ovidius, řečený Publius Naso, autor monumentálních Proměn, byl vypuzen do vyhnanství, které strávil v dnešní rumunské Konstanci. Génia Augusta za to zpodobňovala okřídlená socha $\mathrm{v}$ nadživotní velikosti na náměstích měst.

Obsahu pojmu génius ve vztahu k umění určil místo až Immanuel Kant v Kritice čistého rozumu (1791). Určení se vyskytuje v první části jeho spisu Kritika soudnosti v paragrafu 46 a dalších paragrafech. Hlavní vstupní Kantova teze zní, že „krásné umění je uměni génia“. V dalším pak vymezuje oba pojmy výměru.

Génius je talent (přírodní dar), který dává umění pravidlo. Poněvadž talent jakožto vrozená produktivní schopnost umělce sám patří k př́rodě, dalo by se to podle Kanta také vyjádřit takto: génius je vrozená duševní vloha (ingenium), kterou dává př́roda umění pravidlo. Teze o géniu jako milci př́rody (Günstling der Natur) tak získala legitimitu z pozice stejně geniálního filozofa.

Výtvoru génia, krásnému umění, přísluší originalita, musí být exemplární, nevzniká napodobením, což bylo člověku dáno při narození. $Z$ tohoto vnuknutí pocházejí ony originální ideje. Kant je vztahuje na všechny druhy umění, především na básnictví, z výtvarných umění na sochařství a malířství. Pod pouhé umění krásné hry počitků u amúzického Kanta spadá hudba. Pokud se nespojuje se slovem, je hudba určena jen pro zábavu, př́kladně uvádí Kant „,hudbu u stolu“ (Tafelmusik). Její účel nepodporuje kulturu společenských sil, není estetickým, nýbrž jen př́ijemným uměním. Nepochází z vnuknutí génia, tak jak z něho nepochází ani věda, kterou Kant nazývá mechanickým uměním.

Formalistické a priori Kantovy filozofie umění, které je vázáno jen na zalíbení v čistě hudební formě, vylučuje průnik do hlubších významových, obsahových vrstev hudby, tak jak do nich začal pronikat již Ernst Theodor Amadeus Hoffmann v recenzi Beethovenovy Symfonie č. 5 c moll (Allgemeine musikalische 
Zeitung, Band 12, 1810) a brzy na to pak především Georg Wilhelm Friedrich Hegel $v$ Přednáškách z estetiky (2 sv., 1820, ed. 1835-1838).

Hegel ve své filozofií umění jako krásného ideálu zůstává u Kantova určení, že umění je výtvorem génia, kterým je člověk od př́rody (bohem) nadaný, tedy onen její milec. Na rozdíl od pouhého talentu, schopného dokonalé hry na housle atp., génius je všeobecná schopnost pravdivé tvorby uměleckého díla a energie provádějící vypěstění a uplatnění této schopnosti. Tato vlastnost je dána pouze duchovně uvědomělému subjektu, který je schopen dospět od nitra k reálnému zjevu svých výtvorů, rozumí se k uměleckému dílu. Podstatný rozdíl mezi Kantem a Hegelem spočívá tedy v pohledu na smysl a význam uměleckého díla. Krásou konkrétního tvaru je smyslové vyjádření obsahu patřičnou formou. Hegel se s Kantem rozchází i v pohledu na hudbu, kterou v druhé knize svých Přednášek $z$ estetiky řadí na vrchol systému. Po hudbě jako romantickém umění následuje již jen poezie, Hegel jí míní všechny literární druhy. Hegel není vůbec amúzický, např. v druhé knize Přednášek z estetiky si bere za prŕíklad Bacha, Händla, Mozarta, ale i C. M. von Webera.

Formalistické teorie pozitivistického 19. století upřednostňovaly Kanta před Hegelem, v české estetice a teorii umění tak činil herbartovec Otakar Hostinský. Vrátil se však k Hegelovi v pozdní syntéze Úvodu do estetiky (1909), v níž zachytil vlny nové diltheyovské hermeneutiky. $V$ českém kontextu jsou hodné povšimnutí reakce na Hegela ze strany poetismu i surealismu, v teorii a estetice Karla Teigeho (Jarmark umění) a přímo v poezii laureáta Nobelovy ceny za literaturu Jaroslava Seiferta a dalších. Avšak podobné úvahy by nás vedly př́liš daleko od našeho tématu a od nich ustoupíme.

\section{Hledání génia loci}

Náleží Brnu, do roku 1948 svým postavením hlavnímu městu moravsko-slezské země, dnes už jen jednomu ze čtrnácti statutárních měst České republiky, označení génius loci, tedy pojem, jehož obsah jsme se právě pokusili vymezit. Několika málo pamětníkủm se při kladení takovéto otázky vybaví Janáčkovo jméno a jeho jedinečné hudební dílo, tak jak ve své úplnosti vyzařovalo do světa v mezní politické situaci po komunistickém převratu roku 1948 na brněnském mezinárodním festivalu Leoš Janáček a soudobá hudba v roce 1958.

V hledání vztahů se můžeme i dnes odvolat na samotného Leoše Janáčka, na jeho slavný fejeton Moje město (1927). Napsal ho v situaci, když už byla nad městem „vykouzlena zár svobody, znovuzrozeni 28. ř́ijna 1918“. Podle Janáčkových vlastních slov vzešlo $\mathrm{z}$,toho poznání v Sinfoniettě vidění jistého rozmachu a velikosti města“. Kořeny poznání a vědomí vztahu na význam místa v hudebním díle skladatele sahají hlouběji do minulosti, do letitého Janáčkova života ve „městě“; začínají někdy ve chvíli, když byl ve třinácti letech přijat za chovance fundace Starobrněnského kláštera, ve skutečnosti jeho hudební školy. V té době Janáčka kromě hudby uchvátil i cyrilometodějský kult, který v klášteře pa- 
noval. Janáček se podle všeho zúčastnil i provedení konečného znění Krř́žkovského kantáty Sv. Cyril a Metoděj při velkolepých cyrilometodějských oslavách v brněnských Lužánkách.

Slavnosti roku 1863 se hluboce vryly do Janáčkova národního vědomí, ovlivnily jeho další chování. Jeho slovanství se prohloubilo a uzrálo i v názoru na úlohu slovanské ideje v evropské hudbě. V předmluvě k písňové antologii Kytice národních písní (1891) předpověděl, že hudební idiom lidové písně slovanských národů jednou nahradí dosavadní dominanci gregoriánského chorálu. Studoval sbírky ruských a ukrajinských lidových písní, naslouchal ortodoxním zpěvům při návštěvách Ruska. V brněnském Ruském kroužku, jemuž Janáček po své první návštěvě Ruska $\mathrm{v}$ roce 1896 až do jeho rozpuštění roku 1915 předsedal, přišel do důvěrného styku s ruskou literaturou. I působení Ruského kroužku náleželo k životním projevům české komunity v městě. Při čteních v kroužku Janáček objevil inspirační zdroje několika svých stěžejních hudebních děl údobí 1905-1918. Vztahy na město a jeho místa prolínaly celým Janáčkovým hudebním dílem.

Janáčka přivedlo ke skládání folklorních skladeb v údobí před Jeji pastorkyní národopisné hnutí měšt’anských vlasteneckých spolků, skladby, které pro ně napsal, svou uměleckou formou přesahovaly kantovský limit hudby jako pouhého užitého umění. Nevznikaly jen pro zábavu, svým účelem podporovaly kulturní síly českého měšt’anstva Brna, jehož centrum stále ještě ovládala německá majorita. K folklorním skladbám se vracel i do budoucna, svým duchem a formou vždy znamenaly i umělecký originál.

Přímo na Brno jako na místo se vztahují Janáčkovy četné inspirace z žánru vážné hudby. Vztahují se na Janáčkova jinošská léta prožitá v Klášteře králové na Starém Brně v kantátě Amarus (1897). V emotivně prožívaných vzpomínkách znamenalo toto podivuhodné dílo něco úplně jiného, než zhudebnění Josefa Bohuslava Foerstera Vrchlického básně Amarus na recitovaný text melodramu s doprovodem klavíru.

V torzu Janáčkovy Klavirní sonáty 1. X. 1905 se vyjevily emoce jednapadesátiletého Janáčka, prožívané za vzrušivé situace bojů ve společnosti za ustanovení české univerzity v Brně. Požadavek odpovídal majoritě české populace v celé moravsko-slezské zemi. Když tomuto požadavku nebylo po různých politických manipulacích $\mathrm{v}$ říšském sněmu učiněno za dost, došlo ve městě $\mathrm{k}$ národnostním střetům, do nichž se zapojil Janáček osobní účastí i svým dílem. Nedovedeme si vysvětlit, proč autograf klavírní sonáty po jejím provedení zničil.

Z některých scén opery Osud (1907) a opery Přihody lišky Bystroušky (1923) se dají vyčíst charakteristické výjevy z Janáčkova života. V Osudu se třetí dějství vztahuje na Janáčkovu Varhanickou školu, která fungovala jako médium nanejvýše v jeho představách, jak v nich vždy fungovala i ostatní brunnensia. Nebyly nikdy pouhou kopií skutečnosti. $\mathrm{K}$ místu divadelního děje druhého dějství náleží scenérie a duchovní klima měštanské rodiny, možná že něco z toho bylo i z osobních vzpomínek. V zobrazení prírodních scenérií Přihod lišky Bystroušky se pojí Janáčkovy osobní prožitky z toulek krajinou lesů, vod a strání brněnského okolí, jak o ní pěje básník. 
V dechovém sextetu Mládí (1925) se vedle nostalgických tónů dají vyčíst a vnímat i pocity veselí chovanců fundace, prožitých v zahradách za ponurými klášterními hradbami.

Janáčkova Glagolská mše (1926) sice vznikala na Hukvaldech a v Luhačovicích, dokončil ji však v Brně. Několik jejich částí si naskicoval již roku 1922, avšak žádnou z nich nepoužil. I vznik Glagolské mše se svým způsobem váže na genia loci domečku na Smetanově ulici, který obýval celé dvacetiletí. Předtím vznikaly Janáčkovy skladby $\mathrm{v}$ bytě dávno již zbořeného nájemního domu na Mendlově náměstí, na jehož severní straně se nalézají klášterní budovy Augustiniánů.

Překročíme hranice Janáčkových brunnensii v inspiracích a hudebních dílech. Brno, uprostřed svých architektonických objektů město se svým zvláštním sociálním a kulturním fluidem, se jako takové dotýkalo i vědomí vnímavého Janáčka, inspirovalo ho. Byl vytrvalým pozorovatelem života kolem sebe. Uchovával si $\mathrm{v}$ paměti nejrůznějš́ podněty ze setkání s lidmi a věcmi. Když mu zazněly hudbou, zapisoval si je na místě do not formou nápěvkủ, na procházkách v lužáneckém parku zpěvy svých pěnkavek, nápěvky mluvy Brňanů na ulicích a venkovanů z blízkého okolí na tržišti Zelného trhu. Tradovalo se, že při pravidelných pochůzkách na Kounicově třídě zdravil mondénní dámu, kterou vůbec neznal, nikdy ji neoslovil. Byl pouze zaujat jejím zvláštním zjevem a ,jednáním“ (řečeno podle dramaturgie Konstantina Sergejeviče Stanislavského), jímž ho vlastně oslovovala. Ona tajemná neznámá snad byla Janáčkovi jistým vzorem pro postavu Emilie Marty. Nebyla jí tentokráte rozhodně Kamila Stösslová.

Vracíme naše slovo filozofickým úvahám, které nejsou proti Janáčkovu géniu. Leoš Janáček Kantovu Kritiku soudnosti nikdy nečetl, četl nejvýše eklektiky jeho formalistické estetiky 19. století. Skutečnost, že je podle našeho názoru Janáčkovo hudební dílo projevem vrcholného tvưrčího ducha, že vykazuje originalitu, že není v žádném př́ípadě epigonální, že vyřazuje novotvary do budoucnosti, není zajisté důsledkem vlivu Kantovy estetiky. Tyto naše argumenty pouze potvrzují, že jeho hudba odpovídá ve všeobecných zřetelech (estetickému) umění, tak jak je stanovil Kant ve svém estetickém a priori. Janáček i při vztazích své hudby na brunnensia, jak jsme je právě popsali a jak se vztahuje i na jiné inspirační zdroje např́ílad z literatury, je tedy výtvorem génia; díla jako taková vyvrací Kantovu filozofii hudby jako př́ijemného umění (na rozdíl od jiných); Kant ale prripouští, že by spadala pod pojem umění smyslové hry bez onoho nádechu pouhé ,príjemnosti“; že by tak stoupenci krajních směrů nové hudby mohli získat pro tento druh „hudby“ legitimitu umění.

Janáček negací Kantovy formalistické estetiky nebyl vůbec hegeliánem, Hegela nikdy nečetl. Hegel však svou obsahovou estetikou (řečeno zatím zjednodušeně) nabízí některými idejemi látku k přemýšlení. Obsáhlými reflexemi hudby v Přednáškách $z$ estetiky zdolává amúzika Kanta, kterého ničily písně vojáků z nedalekých kasáren od jeho bydliště, a proto také na hudbu zanevřel. V Hegelově systému zaujímá hudba významné místo, pojednává o ní kvalifikovaně (radil se o ní s hudebními profesionály), odvolával se na díla skladatelů, ve výčtu končí 
Weberovým Čarostřelcem, který slavil svou premiéru v roce dokončení Hegelových Přednášek z estetiky (1820).

Pro Hegelovu hudební estetiku je důležité několik věcí. Všeobecně přiznává hudbě rysy uměleckého díla (,geniality“), které jsou vlastní ostatním uměním, prríkladně však malířství a poezie všech jejích druhů. Na rozdíl od malírství, v němž se objeví vždy určitý odlesk duchovna $\mathrm{v}$ představě malířova subjektu, avšak vždy v zobrazení předmětu v jeho krajní extrémní vnějškovosti; v hudbě.

Jiří Vysloužil působí jako emeritní profesor na Ústavu hudební vědy FF MU. Dlouhodobě se zabývá hudbou 19. a 20. století, zejména hudební lexikografí, folkloristikou, jakož i osobnostmi Leoše Janáčka, Aloise Háby a Karla Husy.

\begin{abstract}
:
One important predecessor of the now traditional annual Brno musicological colloquiums, founded in 1966, was the International Musicological Congress Leoš Janáček and the Contemporary Music in 1958. Several musicologists from both parts of divided Europe, let alone America, Japan and South Africa, were able to meet. The term „Genius loci Brno“ has to be defined not to get confused with mere journalistic praise of local musicians. The suitable definitions of genius can be found in Plato, Kant and Hegel. In search of the Genius loci in Brno, we probably all have Janáček in mind in the first place. His famous feuilleton Moje mésto (My City, 1927) is likely to be the best example. Important constituents of the genius loci of Brno during Janáček's lifetime included the cult of Saints Cyril and Methodius, folk songs and folk culture, Russian culture represented by the Russian Circle (1896-1915), but also the growing tension between the local Czechs and Germans. Many examples of both his and general situation, facts and life are to be found in his operas and other works. His way of looking at things is special. He is denying Kant's formalistic aesthetics.
\end{abstract}

Key words:

Genius loci, Brno, Leoš Janáček, Immanuel Kant, Georg Wilhelm Friedrich Hegel

\title{
Bibliography:
}

HEGEL, Georg Wilhelm Friedrich. Vorlesungen über Ästhetik. 2 sv., 1820, ed. 1835-1838.

JANÁČEK, Leoš. Moje město. Lidové noviny, roč. XXXV, č. 648, 24. 12. 1927.

KANT, Immanuel. Kritik der Urteilskraft. Stuttgart: Philipp Reclam jun., 1963.

PRAŽÁK, Josef M. - SEDLÁČEK, Josef - NOVOTNÝ, František. Latinsko-český slovnik k potřebě gymnasií a reálných gymnasií. Praha: Československá grafická unie, 1935. 